\title{
Multifunctional Counting Tablet (McT) as a Manipulative to Learn basic Mathematics among Malaysian Primary School Pupils
}

Tchong Fui Mui, Bong Sze Sze, Muhamad Mukhzani Muhamad Hanifah, Foo Kien Kheng

To Link this Article: http://dx.doi.org/10.6007/IJARBSS/v11-i10/11452

DOI:10.6007/IJARBSS/v11-i10/11452

Received: 04 August 2021, Revised: 29 August 2021, Accepted: 20 September 2021

Published Online: 11 October 2021

In-Text Citation: (Mui et al., 2021)

To Cite this Article: Mui, T. F., Sze, B. S., Hanifah, M. M. M., \& Kheng, F. K. (2021). Multifunctional Counting Tablet (McT) as a Manipulative to Learn basic Mathematics among Malaysian Primary School Pupils. International Journal of Academic Research in Business and Social Sciences, 11(10), 823 - 830.

\section{Copyright: (c) 2021 The Author(s)}

Published by Human Resource Management Academic Research Society (www.hrmars.com) This article is published under the Creative Commons Attribution (CC BY 4.0) license. Anyone may reproduce, distribute, translate and create derivative works of this article (for both commercial and non-commercial purposes), subject to full attribution to the original publication and authors. The full terms of this license may be seen at: http://creativecommons.org/licences/by/4.0/legalcode

Vol. 11, No. 10, 2021, Pg. $823-830$

Full Terms \& Conditions of access and use can be found at http://hrmars.com/index.php/pages/detail/publication-ethics 


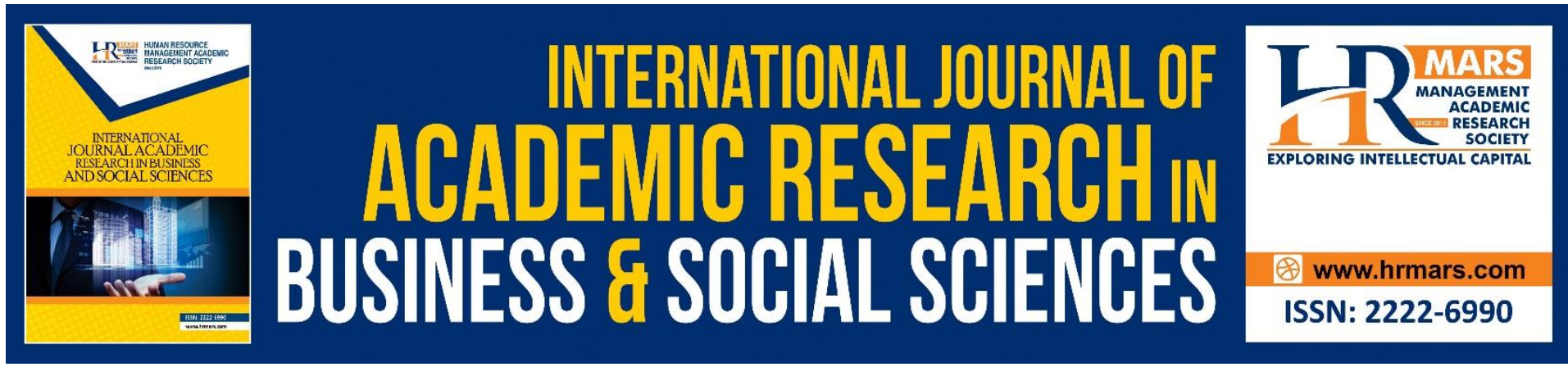

\title{
Multifunctional Counting Tablet (McT) as a Manipulative to Learn basic Mathematics among Malaysian Primary School Pupils
}

\author{
Tchong Fui Mui, Bong Sze Sze, Muhamad Mukhzani Muhamad \\ Hanifah, Foo Kien Kheng \\ SPARKS Education PIt
}

\begin{abstract}
Parents, school administrators and teachers who want to find the best teaching aids for their children or pupils may face the problem of selecting the best teaching and learning tools in particular to manipulatives as they can be expensive. For the learning and teaching of Numbers and Operations in Primary schools there are many to choose. However, having to learn to use and master different aids or manipulatives does pose a problem for pupils and teachers alike. In addition, there is the cost of multiple purchases and storage of these teaching tools. McT provides the perfect solution to overcome these problems. McT is a multifunctional counting tool, a manipulative specially designed for the teaching and learning of Number and Operations in Primary schools for Year 1-3 pupils where traditionally these topics require the use of different teaching tools. The feasibility study indicated the McT has its theoretical foundation to be successful as a potential teaching tool to replace some of the presently used manipulatives in the classrooms. In conclusion, the product design process suggested can be considered a possible conceptual framework to run a research to validate McT.
\end{abstract}

Keywords: Counting Tool, Mathematics, Primary School, Manipulatives, Abacus

\section{Introduction}

In general, Moyer (2001) commented on Jean Piaget's work about young children learn primarily in concrete mode and that the abstract mathematical ideas or concepts are better understood through hands-on activities. Later educational psychologist like Zoltan Dienes developed the Dienes blocks; Caleb Gattegno and Georges Cuisenaire designed the Cuisenaire rods while Bruner's thesis on enactive, iconic and symbolic stages explain the role of the concrete, representation stage before progressing to the abstract. More recent work by constructivist theorists reinforced the benefits of manipulatives to progress to the abstract symbols that make sense to these pupils. Students use mathematical manipulatives, not only does it increase their mathematical achievement scores, but it also provides them with additional methods or strategies that are critical to building problem solving skills (Liggett, 2017).

Abacus is a well-known counting tool throughout history and predecessor to modern 
calculator. There are many versions of abacus, but the build concept is still the same. A compact frame that holds columns of beads that slides on a stick. Generally, traditional abacus was made with high quality wood for durability, ease of material access and the organic features of wood product. these features are still commonly used in most modern abacus production. This does come with drawback. High quality wood does have high durability but it also heavy and expensive. These factors would be not sustainable for the usage especially primary students.

Counting tokens consist of any object that is capable for counting individually. For this study, there are LEGO, building blocks, coin token, counting cubes and counting sticks that are used as teaching aids. The counting tokens are mostly made of plastic, usually ABS or Acrylonitrile Butadiene Styrene and PVC or Polyvinyl Chloride plastic through injection moulding process and no assembly required. Due to that, these tokens are very cheap, durable, lightweight and easy for mass manufacturing. They are also available in many colour variation like Lego and the Cuisenaire rods. One particular benefit of LEGO construction, Lego games or Cuisenaire rods, is that it helps to improve students' involvement, problem solving and motivation in learning mathematics. Apart from that, Cuisenaire rods help students to master abstract concepts using colored cardboard or wooden strips of varying lengths (Kurumeh, 2009).

However, these manipulatives also come with its own drawbacks. Overall, most of these tokens are not environmentally friendly as it is made from plastic. There are other hazardous factors depending on the size of the token. For small tokens such as LEGO and coins, it is easy to lose them. Swallowing hazard is also quite high. Other tokens such as the counting sticks, while having high tendency to be lost, they are also hazardly sharp objects. For large tokens such as building blocks and counting cubes, they need large storage space and can be heavy, posing difficulty in transporting them (see Table 1). Therefore, in order to be viable, the product needs to be durable, compact, easy to carry, made from environmentally friendly materials and produced at the cheapest price.

Table 1: The pros and cons of selected manipulatives

\begin{tabular}{|l|l|l|}
\hline Product & Pros & Cons \\
\hline Abacus & $\begin{array}{l}\text { Durable } \\
\text { Compact } \\
\text { Environmentally friendly } \\
\text { (material) }\end{array}$ & $\begin{array}{l}\text { Heavy } \\
\text { Difficult to produce } \\
\text { Expensive }\end{array}$ \\
\hline $\begin{array}{l}\text { Counting tokens (LEGO, } \\
\text { building blocks, coin token, } \\
\text { cubes, sticks etc) }\end{array}$ & $\begin{array}{l}\text { Durable, } \\
\text { Lightweight } \\
\text { Colourful } \\
\text { Easy to produce } \\
\text { Cheap }\end{array}$ & $\begin{array}{l}\text { Hazardous } \\
\text { sharp ended) } \\
\text { Not environmentally friendly } \\
\text { material (ABS plastic) } \\
\text { Large storage space needed } \\
\text { Easy to lose }\end{array}$ \\
\hline
\end{tabular}

Thus, in introducing these manipulatives, pupils, teachers and administratorsa alike face many challenges like i) coping with learning how to operate the different tools, ii) adjusting 
to the different learning styles and manipulative skills required by each tool, iii) cost of purchasing the manipulatives.

In the Malaysian primary mathematics curriculum (Dokumen Standard Kurikulum Dan Pentaksiran Tahun 1, 2016), 'the teaching and learning process of mathematics gives priority to the mastery of knowledge and understanding which enables pupils to apply concepts, principles and the mathematical processes learnt' with emphasis on mathematical thinking i.e. problem solving, reasoning, communication, represention and connection and use of technology in mathematics. For most part, the use of appropriate teaching tools is strongly recommended by the Ministry of Education.

At the primary level, the use of manipulatives like abacus, Multilink cubes, Dienes blocks, counters, Lego, place value counters, bead strings, Cuisenaire rods, base-ten blocks, place value cards, $10 \times 10$ squares, digit cards, dice, dominoes and so forth are recommended in the learning of Numbers and Operations. However as discussed above, the cost of buying such a vast variety of manipulatives is not only high but particularly difficult for pupils to master everyone of them. This paper sought to recommend an alternative solution to address this issue.

\section{Problem Statements}

Learning of mathematics in primary schools cannot be well understood nor mastered without the use of specific teaching aids or manipulatives (Hughes, 2003; Smith \& Pellegrini, 2008). Cognitive theories over the centuries have taught us that children need to touch, feel, smell and manipulate these physical objects to understand mathematical concepts and it is also a prerequisite to acquire skill sets for advancement to more complicated concepts later (Smith \& Pellegrini, 2008; Muddin, 2013).

However, the need to manipulate a variety of teaching aids must surely require pupils to adapt to a variety of learning styles as well as those of the styles of their teachers (Online, 2013). Herein lies the crux of the problem pupils are facing which is pupils are required to learn to use and master the uses of different aids on a regular basis. In addition, there is the cost of multiple purchases of these teaching tools that could be discouraging to the school administration. It is thus, proposed that the use of a multifunctional counting tool to solve the above problems.

\section{Research Objectives}

1. To investigate the different learning styles and skill sets required of pupils when using the various teaching aids to learn specific content standards in the Malaysian primary school mathematics.

2. To design and develop a manipulative known as Multifunctional counting tablet (McT) in place of the various teaching aids to learn similar content standards in the Malaysian primary school mathematics.

3. To test out the manipulative known as Multifunctional counting tablet (McT) among pupils and teachers in selected Malaysian primary schools. 


\section{Multifunctional Counting Tablet (MCT)}

Table 2: McT to serve the functions of some of these manipulatives

\begin{tabular}{|c|c|c|}
\hline \multicolumn{3}{|c|}{ Manipulatives } \\
\hline
\end{tabular}

The development of McT followed a product design process used by our Research and Development Department:

\section{Product Design Process}

\section{a. Feasibility Study}

A feasibility study was carried out by first exploring and comparing the different functions of the manipulatives shown in Table 1 and Table 2 to list out its pros and cons (refer to Introduction section for a detailed account). A prototype called McT was proposed as an alternative to replace these manipulatives. A pilot study was carried out with a small sample in May 2021 to gauge the acceptance among the users in term of its design and physical attractiveness. For that purpose, a series of interviews on the efficacy and relevance of McT in the primary school classrooms was conducted in Kuching, Sarawak involving two pupils and a parent.

The pupils tried out the teaching aid (McT). The sessions were recorded for analysis. Suggestions for further improvement were also elicited from the parent. Interview findings indicated that the respondents found the McT made the learning process much more fun and easier. They could use the regrouping concept in doing the addition and subtraction of whole numbers. The interview from a parent showed that the McT was innovative - it looked difficult, but after the explanation from the interviewer, the child could do it easily and enjoyed it very much. As the sample size is small, it is suggested that a full research is carried out to comprehensively test if McT does achieve its purported functions and uses as listed in the table below: 
Table 3: Coverage of mathematics content and functions of McT

\begin{tabular}{|c|c|c|}
\hline $\begin{array}{l}\text { Multifunction } \\
\text { al Abacus } \\
\text { Tablet (McT) }\end{array}$ & $\begin{array}{l}\text { Description (Year / } \\
\text { Subject / Topic) }\end{array}$ & Usage (Skill/ Knowledge/ Concept \\
\hline $\begin{array}{l}\text { Multifunction } \\
\text { al Abacus } \\
\text { Tablet (Mat) } \\
\text { For Numbers } \\
\text { And } \\
\text { Operations }\end{array}$ & $\begin{array}{l}\text { Mathematics } \\
\text { Year 1, } 2 \text { And } 3 \\
\text { Topics: } \\
\text { i. Number within } \\
\text { 100, } \\
\text { ii. Number within } \\
1000 \\
\text { iii. Number within } \\
10000 \\
\text { iv. Addition and } \\
\text { subtraction, } \\
\text { v. Multiplications } \\
\text { vi. Division } \\
\text { vii. Problem solving }\end{array}$ & $\begin{array}{l}\text { A. It helps teachers and pupils to learn the concepts of the } \\
\text { following topics: } \\
\text { I. Number } \\
\text { li. Addition And Subtraction, } \\
\text { lii. Multiplications And Divisions } \\
\text { Iv. Problem Solving } \\
\text { B. It can be adapted to become a traditional abacus of } 4: 1 \\
\text { or a soroban while the more complex one is the 5:2 } \\
\text { sempoa. } \\
\text { C. It allows for creative and problem-solving activities by } \\
\text { helping young children to form insights about the logical } \\
\text { relations among the chips and color grouping } \\
\text { D. At the more advanced level, it can be used for math } \\
\text { competition or challenges in class. } \\
\text { Its main utility is to replace the many manipulatives to } \\
\text { teach the same topics or skills with just one manipulative. } \\
\text { Some examples of teaching aids commonly used in the } \\
\text { classrom are abacus, multilink cubes, dienes blocks, , lego, } \\
\text { counters, place value counters, bead strings, cuisenaire } \\
\text { rods, base-ten blocks and others. }\end{array}$ \\
\hline
\end{tabular}

\section{b. Products Conceptualization}

During the feasibility study, a product concept was developed based on these features: multifunction, durable, compact, lightweight, easy to produce, environmentally friendly and cheap. At first it seemed impossible to achieve as some of the criteria contradicted with each other, such as durability. Durable material is usually not lightweight and if it can be lightweight, usually it would be expensive.

With 3D printing technology, all of the criteria can be achieved as 3D printing is able to print the product with variation of internal structure that can optimize the strength and the weight of the final product. 3D printing is also capable of printing in a variation of materials such as plastics, composites and clay.

\section{c. Product Design}

As the product concept is decided to be based on 3D printing technology, the design is subjected to 3D printing manufacturing. A CAD software was used to design the product and the design was mostly based on tablet size as it is a well-known modern shape especially with the current generation. The product is around $220 \mathrm{~mm} \times 250 \mathrm{~mm} \times 3 \mathrm{~mm}$ size. This design has the capacity to do single print manufacturing. What that means is that the product can be printed in single print and still maintain its movability. in other words, the product can be use right away after print. This is a huge advantage in manufacturing as it eliminates assembly 
stage for production. This technique can only be implemented in fused deposition modelling manufacturing (FDM) and most 3D printers are based on this type of process.

\section{d. Tooling Support}

Based on the design, a Fused Deposition Modeling (FDM) 3D printer was used as a tool to make the prototype of the product, making it suitable for small scale manufacturing. This technology greatly helps in reducing the time gap from design to prototyping and manufacturing.

\section{e. $\quad$ Mass Production Support}

As this product is designed based on 3D printing technology, the capability of mass production is relied on what kind of 3D printer that would be used and how many products are needed to be printed.

\section{Discussion and Conclusion}

Research has provided sufficient evidence that manipulatives offer an effective way for pupils to learn math concepts and master skills in different ways. Manipulatives if used constructively can have a significant outcome on the pupils' math skills and motivation (Hurst \& Linell, 2020).

This paper examines the current manipulatives that are in use in our Malaysian classrooms. Literature has shown that though they are important as a learning tool they also posed problems in terms of coping and adapting to the different learning styles and manipulative skills in addition to the high cost of purchasing them. In the longer-term, this paper suggests the use of one manipulative (McT) in place of the need to use a variety of teaching aids that almost serves the same functions as the McT. As McT has not been scientifically demonstrated to be a better alternative, it is recommended that a well-designed study is carried out. In conclusion, McT offers a promising option for the children to learn the topics in Numbers and Operations but evidently it needs to be trialed and validated through user acceptance..

\section{References}

Dokumen Standard Kurikulum Dan Pentaksiran Tahun 1 (2016). Kurikulum Standard Sekolah Rendah Matematik (Edisi Bahasa Inggeris). Bahagian Pembangunan Kurikulum, Kementerian Pendidikan Malaysia.

Hughes, M. (2003). Children and Number: Difficulties in Learning Mathematics. WileyBlackwell Publishing.

Hurst, C., \& Linsell, C. (2020, September 7). Manipulatives and Multiplicative Thinking. European Journal of STEM Education, 5(1). Retrieved from https://files.eric.ed.gov/fulltext/EJ1267965.pdf

Kurumeh, M. S. (2009). Effect of Cuisenaire Rods' Approach on Students' Interest in Decimal Fractions in a Junior Secondary School. Global Journal of Educational Research, 9, 1 \& 2, 25-31.

Larkin, K. (2016). Mathematics Education and Manipulatives: Which, When, How? Retrieved from https://gogalecom.ezproxy.nwciowa.edu/ps/retrieve.do?tabID=T002\&resultListType= RESULT_LIST\&searchResultsType=SingleTab\&hitCount=1\&searchType=AdvancedSearc 
hForm \&tPosition=1\&docld=GALE\%7CA454486842\&docType=Article\&sort=RELEVANCE \&contentSegment=ZEDUMD1\&prodld=PROF\&pageNum=1\&contentSet=GALE\%7CA45 4486842\&searchld=R2\&userGroupName=nwcollege\&inPS=true

Liggett, R. S. (2017). The Impact of Use of Manipulatives on the Math Scores of Grade 2 Students. Brock Education Journal, 26, 2. https://doi.org/10.26522/brocked.v26i2.607

Ministry of Education Malaysia (2016). Textbook Mathematics Part 1 Year 1. Kuala Lumpur, Malaysia: Dewan Bahasa dan Pustaka.

Moscardini, L. (2009). Tools or Crutches: Apparatus As A Sense-Making Aid In Mathematics Teaching With Children With Moderate Learning Difficulties. Support for Learning, 24, 1, 35- 41.

Moyer, P. (2001). Are We Having Fun Yet? How Teachers Use Manipulatives To Teach Mathematics. Educational Studies in Mathematics 47, 175-197.

Muddin, H. N. B. I. (2013). Number Skills Mobile Application for Down Syndrome Children. Information \& Communication Technology. Malaysia: Universiti Teknologi PETRONAS.

Online, E. D. (2013). Learn Faster, Learn Better: What Style Fits You Best? Retrieved from http://www.onlineeducation.net/2013/05/28/types-oflearning

Smith, P. K., \& Pellegrini, A. (2008). Learning Through Play. Encyclopedia on Early Childhood Development, 1-6.

Sulaiman, T., \& Konting, M. M. (2014). The Readiness of Primary One Students in Learning Science Using English. Educational Leadership Journal, 1(1), 1-6.

West, J. (2018). Mathematical manipulatives for misers. Retrieved from https://gogalecom.ezproxy.nwciowa.edu/ps/retrieve.do?tabID=T002\&resultListType= RESULT_LIST\&searchResultsType=SingleTab\&hitCount=1\&searchType=AdvancedSearc hFormatPosition=1\&docld=GALE\%7CA546025218\&docType=Essay\&sort=RELEVANCE \&contentSegment=ZEDUMOD1\&prodld=PROF\&pageNum=1\&contentSet=GALE\%7CA5 46025218\&searchld=R1 \&userGroupName=nwcollege\&inPS=true 